\title{
SOCIETIES' PROCEEDINGS
}

\section{ROYAL SOCIETY OF MEDICINE-SECTION OF OTOLOGY}

October 18th, 1921.

\author{
President-Dr A. Logan TURNer.
}

The President in his introductory remarks thanked the members of the Section for the high honour which they had conferred upon him. He pointed out that the prestige of otology in this country lay largely in the hands of members of the Section. Many problems had still to be solved, and he urged the younger members to concentrate upon some particular piece of investigation which would reflect credit upon themselves and give additional kudos to the position of Otology in this country.

He referred to the recent inauguration, by the American College of Surgeons, of a Department of Literary Research, by means of which analyses, reviews, and statistics of the work of all the Fellows of the College might be collected, and deductions drawn from them upon a broad scale. If the Surgeons in charge of the Departments for Ear, Nose, and Throat diseases in all the large centres in Great Britain would publish annually the reports of their departmental work, really valuable deductions might be drawn from a collective study of them, and the Journal of Laryngology might be utilised as the medium of their publication. During the fifteen years in which he had held the post of hospital surgeon, annual reports had been issued from the department, but these dealt with only a limited amount of material. If the same were produced upon the scale which he suggested, their value would be enormously increased.

He had chosen for the main subject of his address, "The Structural Type of the Mastoid Process based upon the Skiagraphic Examination of rooo Crania of Various Races of Mankind." The investigation had been commenced in $19 \mathbf{I}_{3}$, in conjunction with his friend and colleague the late Major W. G. Porter, D.S.O., formerly a member of the Section, and it was through the energy and enthusiasm of Dr Porter, who had himself radiographed the skulls, that the deductions which he (the President) was about to bring forward had been made possible. The craniological collection in the Anatomical Museum of the University of Edinburgh had been put at their disposal by Professor Arthur Robinson.

(The Address will be published in extenso in the Journal of Laryngology.) 


\section{Royal Society of Medicine}

A Method of Diagnostic Exploration of the Posterior Ethmoidal Cells - Drs P. Watson-Williams and E. WatsonWILliams. (Paper published in the Journal of Laryngology, October I 92 I.)

Case of Vertigo, due to Cholesteatoma of Attic, cured by Ossiculectomy-Sir J. Dundas-Grant.-Female, aged 40 , seen in April r 9ro, complaining of attacks of vertigo with loss of consciousness and occasional double vision, two or three times a month for several months. The left ear had discharged pus off and on since childhood.

On examination there was a large perforation in the attic, through which desquamative material protruded; it was obvious that the cholesteatomatous material was being blocked up by the presence of the ossicles. Ossiculectomy was performed next day, and beyond an occasional slight "swimminess" from that time she had been free from pain and vertigo.

Pigeon Sixteen Months after a Single Application of Alcohol to the left Membranous Labyrinth-Mr Sydney ScotT.When the pigeon is placed on a perch it rotates the head on an anteroposterior axis with the vertex of the head to the left and downwards, so that the right eye looks to the left side and the left eye looks to the right. It will remain in this position for several minutes at a time, and then assumes the normal position unless excited or disturbed.

Dr A. A. GRAY asked whether any loss of muscular tone had been noted, as a theory had been propounded that the labyrinth was the organ of muscular tone.

Mr O'MALLEY wished to know if there had been striking disturbance in equilibrium immediately after the operation.

Mr SYDNEY SCOTT (in reply) said the pigeon was the only survivor, after sixteen months, of the thirteen birds operated upon. Some of the birds had died because they could not feed themselves. The survivor could feed itself, doing so at first by approaching the food sideways. Mr Scott did not know how he could ascertain the existence of loss of tone in the pigeon, and he had never been able to satisfy himself that there was loss of tone in human beings after destruction of the labyrinth, though patients had stated that they were conscious of a feeling of weakness in the extremities on the same side as the labyrinthine lesion.

Case of (?) Ossification of the Tympanic Membrane round a Perforation-Mr T. H. Just.-Female, aged 6o, complained of deafness and tinnitus, especially in the left ear, which had been increasing for the last three years. There was no history of otorrhcea. In the left ear the membrane was scarred and showed a large, dry, posterior perforation, around which was well-marked ossification. The right membrane showed a similar condition, but less advanced.

Tumour of External Auditory Meatus-Mr T. H. JUst.Female, aged 60 , had noticed the swelling for six years. It had 


\section{Societies' Proceedings}

steadily increased, causing deafness. The tympanic membrane was normal. The secretion which accumulated in the meatus did not come from the middle ear.

Patient showing Results after a Bilateral Schwartze Operation-Mr Lionel Colledge.-Female, aged 6, on ist December I920, had the Schwartze operation on the left mastoid for acute suppuration; on 4 th December 1920, a similar operation on the right ear.

The perforation in the tympanic membrane had healed in both ears and all suppuration had ceased. The wound in the right mastoid had filled up and healed in the normal way, but a large, dry cavity persisted in the left mastoid. Both sides were treated in the same manner.

Dr P. MACDONALD had had a similar case in which one side healed up, but on the other, a comparatively large probe could be passed into a cavity. The wound had, at first, been packed with gauze, but later, it had been discontinued. The lining of the cavity was not skin, but the ordinary mastoid cell lining.

Mr SYDNEY SCOTT thought that gauze packing contributed to such a result.

Sir JAMES DUNDAS-GRANT said that, when there was a large mastoid cavity, removal of the posterior osseous meatal wall without perforating the membranous part would allow of collapse of the soft parts into the mastoid cavity.

Mr G. J. JENKINS thought that, in this case, the mucous membrane had not been completely removed from the antrum and that the bone cavity was partly lined with mucosa. If the cavity were large, this would take place rapidly before the granulations at the surface had been able to come together and close the opening.

Extra-dural Abscess with Extensive Sloughing of Dura Mater-Mr Buckland Jones.-Male, aged 25, on 5th August 1920, had slight discharge from left ear with deafness; on I gth April I92 I, severe headaches and tenderness over mastoid. Operation advised, but refused. On I Ith May I92 I, patient admitted collapsed. Mastoid operation performed; antral tegmen found necrosed; large quantity of stinking fluid and pus. Middle fossa was exposed and extensive sloughing of dura found. Lumbar puncture ; cerebro-spinal fluid was clear and sterile.

On I8th May slight rise of temperature and headaches; the opening was extended anteriorly and the temporal muscle divided: a slough 4 in. by $\mathrm{I} \frac{1}{2}$ in. was exposed. A vaccine of Bacillus coli communis and Streptococcus was administered. The slough entirely separated in five to six weeks.

On 7 th October 192 I general condition was good.

Mr SydNeY ScotT related a somewhat similar case in which he had found a large mastoid cavity with a sloughing dura mater exposed by the disease. The latter gave way under pressure of the finger, followed 
by an outpouring of cerebro-spinal fluid as if from a tap, towels becoming saturated with it. The brain cortex did not advance and occlude the opening. The patient did not recover consciousness after the operation, and died in sixteen hours.

Epithelioma of Auricle-Mr Lionel Colledge.-Patient, a male, six weeks before admission, noticed a small pimple on the right auricle; he scratched this and a rapidly developing ulcer formed; the edges were sharply cut; the auricle swollen and tender; small hard glands were palpable over the mastoid process and in the posterior triangle; the cartilage in the floor of the ulcer was necrosed. Pathological report-epithelioma with typical cell nests. Wassermann negative.

Mr NORMAN PATterson advised removal of the auricle and mastoid process, exposure of the lateral sinus, and its closure by a gauze plug between the sinus and the skull, and free dissection of the glands in the neck.

Mr MUSGRAVE WOOdMan favoured a similar extensive operation. He had been struck with the rapidity of growth of epithelioma in the external auditory meatus. He had recently seen a case in which a small epithelioma of the skin of the meatus had grown rapidly, causing facial paralysis, necrosis of the mastoid, exposure of the lateral sinus and infiltration of the dura mater. Post-mortem examination showed invasion of the temporo-sphenoidal lobe by the tumour.

\section{ABSTRACTS}

EAR.

\section{Further Remarks Concerning the Acoustic Neuromas. Harvey}

Cushing. (Laryngoscope, Vol. xxxi., No. 4, p. 209.)

The author has collected 639 verified brain tumours; of these 7.3 per cent. were acoustic neuromas; of all tumours with symptoms pointing unmistakably to the cerebellopontine angle, the larger percentage were acoustic neuromata ( 47 in 60 cases).

The present series consists of 19 cases, and the operation mortality is 15.8 per cent. as compared with 20.7 per cent. in the previous series of 29 cases. If two cases, which died forty-six and fifty-two days after operation from other than operative complications, were omitted, there would only be one fatal result in Io cases. Fourteen of this series presented straightforward symptoms, and the result in each case was satisfactory. Histories of the fatal cases are given. It is regrettable to read of the numerous nasal operations some of the cases had undergone for cure of deafness or as a diagnostic measure.

Dr Cushing is strongly in favour of the suboccipital route, and 